\title{
Relationship between some Hematologic Parameters (ESR, CBC) and CD4- Positive Lymphocyte Count in HIV Sero-Positive Anti-Retroviral-Naïve Individuals with Tuberculosis Co-Infection
}

\section{Ogbonna Collins Nwabuko 1,2,3*}

${ }^{1}$ Department of Hematology and Blood Transfusion, Federal Medical Center, Umuahia, Abia State, Nigeria

${ }^{2}$ Department of Hematology, College of Health Science, Abia State University, Aba Campus, Abia State, Nigeria

${ }^{3}$ Department of Public Health Sciences, Walden University, Baltimore, USA

\begin{abstract}
Background: The objective of this study was to determine the relationship between hematologic parameters such as Erythrocyte Sedimentation Rate (ESR), Complete Blood Count (CDC) and CD4-positive T-lymphocyte count in HIV sero-positive anti-retroviral naïve patients and their relevance as predictive markers of HIV disease progression.

Method: Fifty (50) conservative highly anti-retroviral naïve HIV sero-positive adult patients and 50 age and sexmatched controls were prospectively studied. A detailed history was taken and full physical examination conducted. ESR, Acid Alcohol Fast Bacillus (AAFB) and Complete Blood Count were carried out.

Results: The mean ( \pm SD) ESR in the patients $(97.46 \pm 39.9 \mathrm{~mm} / \mathrm{hr}$ ) was significantly higher than that of the controls $(10.1 \pm 5.7 \mathrm{~mm} / \mathrm{hr})(p<0.001)$. The mean CD4-positive lymphocyte count of the patients $(217.7 \pm 144.8$ cells/ $\mu \mathrm{l})$ was significantly lower than that of the controls $(896.2 \pm 198.0 \mathrm{cells} / \mu \mathrm{l})(p<0.001)$. There was no significant difference between the mean ESR and the CD4 positive lymphocyte count of HIV/TB co-infected patients (134.0 $\pm 24.2 \mathrm{~mm} / \mathrm{hr}$ and $128.7 \pm 114.0 \mathrm{cells} / \mu \mathrm{l})$ from that of HIV infected without tuberculosis co-infection $(95.0 \pm 39.6$ $\mathrm{mm} / \mathrm{hr}$ and $223.4 \pm 113.7 \mathrm{cells} / \mathrm{\mu l}$, respectively). There was a weak inverse correlation between the CD4-positive lymphocyte count and ESR in both control and the patients $(r=-0.18 ;-0.11$, respectively) $(p<0.001)$. The hematocrit and Absolute lymphocyte count (ALC) of the HIV patients $(0.33 \pm 0.08 \mathrm{~L} / \mathrm{L}$ and $3.500 \pm 1.263$ cells/ $\mu$ l respectively) were significantly lower than that of controls $(0.43 \pm 0.045 \mathrm{~L} / \mathrm{L}$ and $4.746 \pm 1.131 \mathrm{cells} / \mu \mathrm{l}$ respectively $)$. The Platelet counts became statistically lower than the controls when CD4 counts $<500$ cells $/ \mu l(p=0.003)$. Hematocrit and ALC had weak direct correlations of 0.07 and 0.18 , respectively with CD4-positive lymphocyte counts of HIV infected patients.
\end{abstract}

Conclusion: ESR, Hematocrit, ALC and Platelet count are useful predictive markers of HIV disease progression although they may not be useful surrogates for CD4 positive lymphocyte count.

Keywords: HIV/AIDS; ESR; CBC; CD4-positive T-lymphocytes; Anti-retroviral naïve patients; Tuberculosis

\section{Introduction}

One of the public health problems of this age is HIV/AIDS pandemic. The consequences could be devastating, dehumanizing, and debilitating especially in developing countries in sub-Saharan Africa. Every day, over 6800 person become infected with HIV. Over 5700 person die from AIDS worldwide; mostly because of inadequate access to HIV prevention and treatment services. Sub-Saharan Africa has been hit harder by HIV/AIDS pandemic than any other region of the world. At the end of 2007, the Joint United Nations Program on HIV/AIDS (UNAIDS) estimated that, globally, 33.2 million adults and children were living with HIV/AIDS, out of which 22.5 million (about $68 \%$ of total number of People Living with HIV/AIDS, globally) were in sub-Saharan Africa. The global HIV incidence for 2007 was 2.5 million while 2.1 million deaths due to HIV-associated diseases were recorded. Sub-Saharan Africa remains the most seriously affected region with AIDS remaining the leading cause of death there. The estimated number of deaths due to AIDS in this region in 2007 was about 1.6 million (76\% of global AIDS deaths in 2007) [1,2].

Nigeria is Africa's most populous nation with a population estimated at well over 140 million in 2006. The adult HIV prevalence has increased from $1.8 \%$ in 1991 to $4.5 \%$ in 1996 to $5.8 \%$ in 2001 . Thereafter the prevalence decreased from $5.0 \%$ in 2003 to $4.4 \%$ in 2005 . That is to say that about 6.6 million Nigerians (4.4\% Nigerians) are living with HIV/AIDS. Rivers state, a state in the Niger Delta Region of Nigeria, accounts for about 350,000 (about $6.5 \%$ of over 5 million indigenes of Rivers state are living with HIV/AIDS) [3].

The impact of the epidemic on the social and economic development of Nigeria has been substantial. It has contributed to the present decrease in life expectancy from 53 years in 1990 to 51 years in 2002[4]. It has increased the number of deaths of young adults and increased the number of orphans in the country (estimated at one orphan in every 15-24 HIV/AIDS-related death). It has also increased the cost of achieving developmental goals and increased the level of poverty in the country. It threatens to cause even socio-economic problems if the epidemic is allowed to further escalate.

*Corresponding author: Ogbonna Collins Nwabuko, Department of Hematology and Blood Transfusion, Federal Medical Center, Umuahia, Abia State, Nigeria, Tel: 2347069337998; E-mail: ogbollins2002@yahoo.com

Received November 09, 2017; Accepted June 22, 2018; Published June 29 2018

Citation: Nwabuko OC (2018) Relationship between some Hematologic Parameters (ESR, CDC) and CD4-Positive Lymphocyte Count in HIV SeroPositive Anti-Retroviral-Naïve Individuals with Tuberculosis Co-Infection. J Blood Lymph 8: 212. doi:10.4172/2165-7831.1000212

Copyright: (c) 2018 Nwabuko OC. This is an open-access article distributed unde the terms of the Creative Commons Attribution License, which permits unrestricted use, distribution, and reproduction in any medium, provided the original author and source are credited. 
The Federal Ministry of Health, as part of measures to respond to HIV/AIDS epidemic in this region, had to scale up the care, treatment, and support of people living with HIV/AIDS through various agencies and non-governmental organizations (NGO's) [4]. However, one of the greatest health challenges facing HIV-related care in the Niger Delta region is the evaluation of baseline CD4 positive lymphocyte count of HIV sero-positive individuals, a parameter essential in the decision-making process of when to start Highly Active Anti-retroviral Therapy (HAART) [5]. The Human Immunodeficiency Virus (HIV1/2) has been documented as the causative agent of Acquired Immune Deficiency Syndrome (AIDS). This virus belongs to the lentivirus family of the retroviruses. Structurally, it exists as a cell-free enveloped particle with genomic viral RNA covered with a protein coat. It is transmitted primarily through sexual contact, parenteral exposure to blood or blood products and prenatally from infected mothers to their infants.

The hallmark of HIV infection is the cytopathic effect on CD4-positive lymphocytes (Helper T4 cells) sub-population of T-lymphocytes, which are the main target cells of HIV. Apart from these cells, other CD4-positive bearing cells such as macrophages, B-lymphocytes, microglial cells of the brain, hemopoietic stem cells, rectal mucosal cells, Kupffer cells, and liver sinusoidal epithelial cells are also affected. The affinity has to do with the existence of structures (receptors) on the virus that get attracted and attached to specific structures on the target cells [6]. This virus gains access to the target via a hydrophilic attachment to the CCRX molecule. This result in the destruction of the CD4-positive cells notably T-helper cells, natural killer cells, and other immune-responsive cells. This results in loss of cytokine synchrony with up-regulation of $\mathrm{CD} 8^{+}$cells and downregulation of $\mathrm{CD}^{+}$cells, interleukins (IL-2, IL-12) and interferon involved in cell-mediated immunity. There could also be an oncogenic transformation of the infected cell by the virus [6]. A CD4-positive lymphocyte is a subset of the T-lymphocyte derived from the lymphoid lineage of the white blood cells. It plays an essential role in the regulation of the immune response (cell-mediated immunity), hence, it is called T-helper lymphocyte. CD4-positive lymphocytes account for about $70 \%$ of the circulating lymphocytes in the body. The normal estimated reference range for HIV sero-negative adults from a study was between 500-1000 cells/microlitre of blood [7]. However, in HIV sero-positive patients, the value falls below the average reference range. CD4-positive lymphocyte count is, therefore, invaluable immune predictor and a prognostic marker in HIV/AIDS management. However, its assessment is expensive and not readily available in all centers. Erythrocyte Sedimentation Rate (ESR) is a test which measures changes in plasma protein patterns which occur in inflammatory and malignant conditions. Chronic infections due to HIV/AIDS that lead to depletion of $\mathrm{CD} 4$ positive lymphocyte count and elevation of concentrations of plasma proteins cause elevation of ESR. It is, therefore, an inflammatory predictor and a prognostic marker. The normal estimated reference ranges for adults in a study are $0-7 \mathrm{~mm} /$ hour for male and 0-15 mm/hour for female. Unlike CD4-positive lymphocyte count, ESR is very cheap, available at any health center and can be easily performed with minimal training. It is worthy of note that an inverse relationship exists between CD4 positive lymphocyte count and ESR based on the pathogenesis of HIV/AIDS and recent studies on HIV-infected antiretroviral-naive patients in different parts of the world. Hence, simple low-cost available laboratory test such as ESR, $\mathrm{CBC}$ can be evaluated as surrogate for $\mathrm{CD} 4$ positive lymphocyte [8]. The present research was aimed at determining the relationship between CD4 positive lymphocyte count and some hematological parameters (i.e., ESR, CBC) of HIV-infected individuals, and to ascertain if they could be used as surrogates for CD4-positive lymphocyte counts in resource-limited settings like the Niger Delta region. This was achieved, using HIV-infected antiretroviral-naive patients recruited at the Hematology clinic of the University of Port-Harcourt Teaching Hospital (UPTH). Investigation facilities determine accreditation for donor driven therapy. Therefore, in order to increase access to antiretroviral treatment, there is a need to evolve low-cost tests.

\section{Literature Review}

One of the public health challenges of this age is that posed by infection with Human Immunodeficiency Virus HIV, and its advanced clinical syndrome, Acquired Immune Deficiency Syndrome, AIDS (HIV/AIDS).The average number of People Leaving with HIV/AIDS is progressively rising in oil-rich cosmopolitan cities of the Niger Delta region of Nigeria with very limited diagnostic technology. A recent study suggested that about 3 out of every 100 healthy young adult men who voluntarily come to donate blood in University of Port Harcourt Teaching Hospital Blood Bank is already infected with HIV [9]. Considering the permissive, cosmopolitan nature of the Port-Harcourt city, the multiplier effect will be enormous in the general population. CD4-positive lymphocyte count is arguably one of the most valuable laboratory parameters for decision- making in the management of HIV disease. It is a useful prognostic marker in predicting the initial response to Highly Active Antiretroviral Therapy (HAART) and in determining the optimal time to initiate therapy $[10,11]$. The CD4positive lymphocyte reference range of healthy HIV-negative Nigerian adults in Port-Harcourt is $647 \pm 93$ cells/microlitre, a value twice that of HIV-infected without AIDS-defining illness (314 \pm 45 cells/ microlitre). The CD4-positive lymphocyte count of HIV-infected with AIDS-defining illness is one-fourth or less (148 \pm 30 cells/microlitre). By World Health Organization definition, CD4 cell count less than 200 or a CD4/CD8 ratio less than 0.14 , along with a positive HIV test constitute 'AIDS' [7].

However, the capacity for measuring CD4 count is not widely available in resource-limited countries. Hence, simple low-cost laboratory tests such as ESR, Total Lymphocyte Count (TLC), and other $\mathrm{CBC}$ parameters are evaluated as surrogates for CD4 count especially when it falls below 200 cells/microliter [8]. This could act as a useful guide in treatment decisions for starting Highly Active Antiretroviral Therapy (HAART). Infection induces an acute phase inflammatory response, which is marked by changes in the concentrations of a number of plasma proteins and lipid. An acutephase protein is defined as one whose plasma concentration increases (positive acute-phase protein, i.e., C-reactive protein, haptoglobin and $\mathrm{a}_{1}$-acid glycoprotein) or decreases (negative acute-phase protein such as albumin, and transferrin) by at least $25 \%$ during inflammatory disorders [12]. The changes in their concentrations are due largely to changes in their production by hepatocytes which are also CD4-positive bearing cells in the liver. ESR is the length of the column of clear plasma (in $\mathrm{mm}$ ) above stacked red blood cells (sedimented red cells) in a Westergren calibrated capillary tube measured after 60 minutes. It is a highly sensitive non-specific hematological test, reflecting changes in plasma protein patterns notably fibrinogen, C-reactive proteins and immunoglobulin (acute phase proteins) which occurs mainly in response to inflammatory and malignant processes. ESR, therefore, acts as a useful predictive marker for acute phase reactant proteins. Disease conditions that lead to elevation of plasma proteins such as fibrinogen, immunoglobulin, and C-reactive proteins will cause elevation of ESR. It indirectly assess, C-reactive protein activity and it is a cheaper and easier laboratory test which can be offered by any 
Citation: Nwabuko OC (2018) Relationship between some Hematologic Parameters (ESR, CBC) and CD4-Positive Lymphocyte Count in HIV SeroPositive Anti-Retroviral-Naïve Individuals with Tuberculosis Co-Infection. J Blood Lymph 8: 212. doi:10.4172/2165-7831.1000212

laboratory in resource-limited settings [13]. ESR has been used for many years as diagnostic aid for conditions associated with acute and chronic inflammation including infections (e.g., HIV/AIDS), cancers (e.g., multiple myeloma), autoimmune diseases (e.g., Rheumatoid arthritis, Systemic Lupus Erythematosus, SLE), cardiovascular diseases (e.g., Myocardial Infarction), pregnancy and use of oral contraceptive pills. ESR is a non-specific test because an increase in value does not tell the doctor exactly where the inflammation is localized or the etiology, and also because it can be affected by other conditions besides inflammation. An elevation in ESR neither reflects specificity nor inflammatory specificity. It is, therefore, an adjunct to other tests like Lactate Dehydrogenase (LDH), beta 2 microglobulins (beta $2 \mathrm{M}$ ), IgA, absolute white blood count (WBC), and absolute lymphocyte count (ALC) [14].

Previous studies in Western cities, like San Francisco in the United States of America, have demonstrated ESR and Lactate Dehydrogenase (LDH) as useful predictive laboratory markers which are usually elevated in opportunistic infection such as Pneumocystis jiroveci. ESR was noted as a low cost and easily available test which improves the ability to diagnose AIDS-Related Complex (ARC), hence a useful predictive marker of low CD4-positive lymphocyte count in resource-limited environment [15]. Similarly, recent studies have shown that increase in ESR in HIV sero-positive patients seem to constitute a predictive marker of progression towards AIDS, even before the decrease of CD4-positive lymphocyte count [8]. This study described ESR elevation as a predictor of morbidity and mortality in HIV infection. This agrees with similar studies in developing countries where ESR was shown as a better predictor of AIDS than CD4 count despite the fact that the latter is traditionally accepted to be one of the essential criteria for the diagnosis of clinical AID syndrome [16]. This could be possible because apart from HIV-induced lymphopenia, there are several conditions associated with CD4-positive lymphopenia. Hence, low CD4-positive lymphocyte counts could proceed other infections and could not have been caused by HIV [17,18]. Several studies have documented the association between tuberculosis (TB) and HIV [19-22]. HIV infection is known to be the most powerful factor that increases the risk of tuberculosis. In the absence of HIV infection, the lifetime risk of developing tuberculosis is $5-10 \%$ or more. In Nigerians who are HIV sero-positive, increased rates of between 2.2-70\% have been documented [23-28]. Similar associations have also been observed in several African countries. HIV decreases the immunecontrol of latent tuberculosis infection, which greatly increases the risk of reactivation of active disease [29-33]. Tuberculosis acts as a cofactor in the pathogenesis of HIV infection and it is observed to be the most important respiratory disease in HIV-infected patients in Africa which, unlike most other opportunistic infections, can be transmitted to other susceptible individuals including those not infected with HIV. Tuberculosis can, therefore, occur at any CD4 level in HIV infection. A recent study showed the evidence for why tuberculosis strikes early in HIV disease to be due to impaired Mycobacterium tuberculosismediated apoptosis in alveolar macrophages from HIV sero-positive person [34]. The study showed that HIV produced elevated lung levels of interleukin-10 that was responsible for reduced tumor necrosis factor-dependent TB-mediated apoptosis of alveolar macrophages in person with HIV infection. This effect was promoted by BCL-3, a protein in ovarian mesothelial cells. The end effect was a reduced ability to control tuberculosis [34].

Consequently, tuberculosis-associated increase in cell activation and cytokine production, such as Tumor Necrosis Factor and Interleukin-6, has been suggested as a possible mechanism for the induced CD4-positive lymphocyte cell loss. This may account for the T-cell depression and reversed CD4/CD8 ratio. It may also account for the high rates of HIV disease progression to full-blown AIDS in Tuberculosis-infected individuals. There is, therefore, a synergic depression of CD4-positive lymphocyte cells in HIV/TB co-infected patients. Tuberculosis is, therefore, the leading killer in HIVinfected individuals, whilst HIV, on the other hand, has emerged as the strongest known risk factor allowing latent remotely acquired Tuberculosis infection to progress to overt clinical Tuberculosis. Hence, real T-helper lymphopenia is, therefore, only consistent with and not diagnostic of AIDS. Even though it is now a useful parameter used to diagnose AIDS; other diseases and some treatment regimen also can express T-helper lymphopenia, as occurs in hospitalized non-AIDS intravenous drug abusers [35]. Other causes of T-Helper lymphopenia are malnutrition, chemotherapy, Di-George Syndrome which is a congenital T-Cell function deficiency caused by a failure of development of the thymus, etc. One of the commonest causes of T-cell (CD4) immune deficiency worldwide is Protein Energy Malnutrition (PEM) in developing countries. Other conditions likely to suppress CD4-positive lymphocyte count include parasitic infections especially those with known immune suppressive activity such as Strongyloides faecalis infection. The coexistence of all these conditions in the same subject makes it difficult to identify patients with AIDS on the basis of current epidemiological and immunological aberrations [36]. The striking findings are that most of the non-HIV-induced CD4-positive lymphopenic conditions enumerated above coexist commonly in HIVinfected individuals in developing countries including those in the Niger Delta region. The same conditions account for increased ESR in the subjects. It is worthy of note that a reliable relationship exists between Absolute Lymphocyte Count (ALC) and CD4 count. In a study done recently, an ALC less than 1000 cells/microlitre, is predictive of a CD4 cell count less than 200 cells/microlitre and an ALC greater than or equal to 2000 cells/microlitre is predictive of a CD4 count greater than or equal to 200 cells/micolitre [37]. However, in University of Port Harcourt Teaching Hospital, a study has been done on the correlation between absolute and CD4 -positive lymphocyte counts in HIVinfected Nigerians. This study showed a modest correlation between CD4-positive lymphocyte count and ALC and further elaborates that though ALC is not an excellent predictor of CD4 positive lymphocyte count, it may serve as an inexpensive and readily available minimal alternative to other non-readily available and expensive methods of CD4-positive T-lymphocyte measurement. It could also be used in combination with WHO disease staging and clinical status of patients in assessing prognosis, guiding the initiation of treatment and subsequent monitoring of patients in resource-limited settings of sub-Saharan African Countries [5]. It is also important to note the effects of other Hematological parameters such as hematocrit, absolute white blood count (WBC) and platelet count on ESR and CD4 positive lymphocyte count in the HIV-infected subjects. In a recent study in which precise measurement of the rate of sedimentation of whole blood was carried out, the concentration of red blood cell and plasma proteins were systematically varied in a $200 \mathrm{~nm}$ blood column after 60 minutes. It was found that an increase in the hematocrit (Packed Cell Volume, PCV) or albumin concentration (negative acute phase protein) inhibits erythrocyte sedimentation rate, whereas an increase in the concentration of globulin or fibrinogen (positive acute phase proteins) accelerates the ESR, with fibrinogen showing more marked effect. It, therefore, implies that decrease in hematocrit (e.g., anaemia) will tend to favor increase in ESR while increase in hematocrit (e.g., polycythemia) will favor a decrease in ESR. In addition, conditions that lead to hypoalbuminemia will likely cause elevated ESR [38,39]. 
Citation: Nwabuko OC (2018) Relationship between some Hematologic Parameters (ESR, CBC) and CD4-Positive Lymphocyte Count in HIV SeroPositive Anti-Retroviral-Naïve Individuals with Tuberculosis Co-Infection. J Blood Lymph 8: 212. doi:10.4172/2165-7831.1000212

Page 4 of 10

HIV destroys and disturbs the seeming bone marrow equilibrium leading to bone marrow cytopaenia. It has a direct cytopathic effect on almost all the cell lineages including CD4-positive lymphocytes, monocytes, macrophages, megakaryocytes, dendritic cells and hemopoietic stem cells. It can also damage bone marrow accessory cells or stromal cells which may lead to overproduction of cytokines such as interleukin-1 alpha( IL-1a), interleukin-6 (IL-6), tumor necrosis factor-alpha (TNF-a) and interferons (IFN), which have inhibitory effects on normal marrow progenitor cells involved in hemopoiesis. The consequences could be decreased hematopoiesis leading to cytopenias in varying combinations such as anaemia from decreased erythropoiesis; decreased granulopoiesis leading to granulocytopenia, decreased lymphopoiesis which causes lymphopenia especially T-cell lymphopenia (CD4 ${ }^{+}$lymphocyte depletion) and decreased megakaryopoiesis which may lead to thrombocytopeniav [40]. Apart from bone marrow cytopenia due to a direct cytopathic effect of the virus on bone marrow progenitor cells, HIV-infected individuals are prone to immune cytopenias. This could be explained by studies which have shown increased serum concentration of gamma globulin (antibody activity) as HIV disease progresses to an advanced stage (AIDS), a condition that may ultimately lead to polyclonal hypergammaglobulinopathy involving $\operatorname{IgA}$, IgG and rarely IgM [41,42]. Among this group is immune thrombocytopenia which can be seen in all stages of HIV infection. It is due to higher proportion of Platelet-bound IgG and complement proteins in the infected patients, a condition known as platelet autoimmunity. These cause a peripheral destruction of platelets by phagocytic cells in the spleen. This thrombocytopenia is evidenced by normal or increases in the number of bone marrow megakaryocytes. A specific antibody known as 7SIgG antiplatelet antibody has been demonstrated in some HIV antibody positive patients [41]. Similarly, HIV-infected patients are prone to immune-mediated neutropenia which may be found in both symptomatic and asymptomatic subjects. This may be due to immune neutrophil destruction resulting from elevated antineutrophil antibodies in some HIV-antibody positive patients. Though these patients may tolerate neutropenia, they are prone to recurrent infection especially if the neutrophils count fall below $500 \mathrm{cells} / \mathrm{mm}^{3}$. However, the striking thing about the neutropenia in HIV-infected is that it responds favorably to recombinant growth factors such as GM-CSF and G-CSF. Furthermore, there is a place for autoimmune hemolytic anemia in the etiopathogenesis of anemia in HIV-infected individuals. Apart from other known causes such as reticuloendothelial iron block, intercurrent infections, marrow infiltration with lymphoma cells, hemophagocytic syndrome and drug therapy (for those who have commenced therapy e.g., azidothymidine), about $6-43 \%$ of HIVantibody positive patients react positively to direct antiglobulin test (DAT, also known as direct Coombs test ) and this is assumed to result from IgG or complement or non-specific immune complexes directed against their red cell membrane phospholipid antigens[40,43]. In all the immune cytopenias encountered in HIV-infected individuals, both the antibodies and complements are elevated. These antibodies (immunoglobulin), immune complexes and complement proteins which are acute phase proteins may account for the raised ESR in these patients. This current research is aimed at determining if ESR and CBC parameters such as hematocrit, $\mathrm{ALC}, \mathrm{WBC}$ and platelet counts can be useful predictive markers for HIV disease progression (with respect to their relationship with CD4-positive lymphocyte count) and whether they can be a suitable parameters for making decision for the initiation of Highly Active Antiretroviral Therapy (HAART) in collaboration with WHO clinical staging criteria in resource-limited areas like the Niger Delta region of Nigeria. It is also aimed at determining the CD4- positive lymphocyte count range at which ESR becomes much relevant as a predictive marker.

\section{Aims and Objectives}

- To carry out a comparative study of CD4-positive T-lymphocyte count, ESR and Complete Blood Counts of HIV sero-positive patients with that for the normal population (control).

- To compare the pattern of CD4 -positive lymphocyte count and ESR results between HIV/TB co-infected patients and that of Tuberculosis-negative patients who are HIV sero-positive.

- To determine the statistical relationship between ESR and CD4-positive lymphocyte count of Antiretroviral-naïve HIV sero-positive patients.

- To determine the correlation between $\mathrm{CD} 4^{+}$lymphocyte count and other hematological parameters such as $\mathrm{PCV} / \mathrm{Hb}$ concentration, absolute white blood count (WBC), Absolute lymphocyte count (ALC) and platelets count of ARV-naïve HIV sero-positive subjects.

- To determine the relationship between $\mathrm{CD}^{+}$lymphocyte count, ESR with the patients' anthropometric parameter (i.e., Body Mass Index (BMI))

\section{Materials and Methods}

\section{Study site}

The study was carried out at the University of Port Harcourt Teaching Hospital (UPTH), Port Harcourt, Rivers State, Nigeria. Port Harcourt is the capital city and administrative headquarters of Rivers State. It is bounded on the south by the Atlantic Ocean, to the north by Imo and Abia states, to the east by Akwa Ibom state, and to the west by Bayelsa state. Port Harcourt is located in the oil-rich Niger Delta region of River State. It is one of the most industrialized cities and the nerve center of the oil industry in Nigeria. It has an international airport, two seaports and a railway terminus, and is well-linked by roads to other parts of the country. The University of Port Harcourt Teaching Hospital is a 1000 bed tertiary health facility which renders specialist HIV/AIDS-related care in the cosmopolitan oil-rich city of Port Harcourt. The hospital serves as one of the designated centers for the Federal government of Nigeria assisted antiretroviral therapy program. University of Port Harcourt Teaching Hospital is chosen based on its central location in the metropolis where it offers tertiary health care services for the inhabitants of Rivers state. It also serves as a referral center for the neighboring states of Bayelsa, Delta, Akwa Ibom, Abia and Imo states. These states account for about $15.5 \%$ of the Nigerian population estimated at 140 million from 2006 Census [44].

\section{Study design}

This was a comparative study carried out to determine the relationship between ESR, CBC and CD4 positive lymphocyte count of HIV sero-positive anti-retroviral naïve patients. The study was divided into three groups based on the $\mathrm{CD} 4^{+}$lymphocyte count of the subjects namely: those with CD4-positive lymphocyte count below 200 cells per microlitre and (Group I); those with CD4 positive lymphocyte count of 200 cells per microlitre to 499 cells per microlitre (Group II) and those with CD4 positive lymphocyte count $\geq 500$ cells/microlitre (Group III). The essence of this comparative study was to ascertain the category of CD4-positive lymphocyte counts with the highest statistical test of significance in this population. It assessed if Erythrocyte Sedimentation 
Rate CBC are useful predictive and surrogate markers for CD4-positive lymphocyte count of HIV infected population in resource-limited settings like the Niger Delta region of Nigeria.

\section{Study population}

The study population was HIV-infected, previously antiretroviralnaïve subjects of both sexes aged 18 years and above enrolled into the antiretroviral therapy program at the Hematology department of the University of Port Harcourt Teaching Hospital (UPTH) within 2008. The choice of the age is explained by the fact that the hospital runs two HIV/AIDS-related care programs; one for Pediatric age group less than 18 years and another for adults 18 years and above. The Hematology clinic handles HIV/AIDS-related care for adults 18 years and above. In addition to this, a comparative study between HIV sero-positive patients and normal selection (healthy blood donors) was carried out. The HIV patients were further classified into Tuberculosis positive and Tuberculosis negative groups by sputum acid alcohol fast bacillus test (AAFB). Clinical details such as weight, height, Body Mass Index (BMI), pigmentation and other AIDS indicator signs and symptoms were documented.

\section{Sample size}

This was determined using the formula:

$\mathrm{N}=\frac{\mathrm{Z}^{2} \mathrm{pq}^{*}}{\mathrm{~d}^{2}}\left({ }^{*}\right.$ Milton JS.Statistical methods in biology and health sciences intern. Students edition).

\section{Where}

$\mathrm{N}=$ minimum sample size.

$\mathrm{Z}=$ standard normal deviate of 1.96 (from $\mathrm{z}$ table) corresponding to 95\% confidence level.

$\mathrm{P}=$ best estimate of HIV sero-positive anti-retroviral-naïve subjects that will have ESR that will correspond with CD4 positive lymphocyte counts. (7.3\%)

$\mathrm{q}=1-\mathrm{P}$

$\mathrm{d}=$ absolute precision $(5 \%$ or 0.05$)$

The value of the sample size is fifty patients (50).

\section{Ethical clearance}

Ethical clearance for the study was obtained from the ethical committee of the University of Port Harcourt Teaching Hospital.

Written and informed consent was obtained from all the HIV infected individuals before being enlisted into the study.

\section{Survey Procedure}

A total of fifty (50) HIV infected previous antiretroviral-naïve subjects aged 18 years and above presented at the Hematology clinic of the University of Port Harcourt Teaching Hospital who met the inclusion criteria were recruited. Each participant completed a serially numbered questionnaire administered by the researcher after being duly informed of the intended study. The questionnaires required respondents to provide vital and full clinical information on possible risk factors for acquiring recent infection including occupation, sexual behaviors, previous sexually transmitted infection, chronic cough, previous blood transfusion and previous surgery.

\section{Specimen collection and laboratory method}

A verbal consent to participate in the study was obtained from the patients. The screening was proceeded by observation of standard aseptic procedures and universal safety precautions in samples collected, stored and processed [45]. About ten (10) milliliters of whole venous blood samples were collected by clean venepuncture using a 10 milliliters hypodermic syringe and needle from each patient. About two (2) milliliters and three (3) milliliters of the blood were placed inside dipotassium EDTA (ethylene diamine tetra-acetic acid or sequestrene) anti-coagulated plastic bottles for CD4 test and ESR (with $\mathrm{CBC}$ ) analysis respectively. The remaining 5 milliliters of blood was put in a plain tube without anticoagulant; centrifuged at 3000 rpm for 10 minutes and serum samples obtained. The serum sample was screened for the presence of HIV antibodies using EnzymeLinked Immunosorbent Assay (ELISA) technique. In this study, Second ELISA technique was used. The first was Genescreen (Sanofi, Pasteur) test kit. All initial reactive samples were re-tested with another ELISA test kit (Biorad, France) for the purpose of eliminating those samples presenting false reaction at the initial stage. Serum samples that were positive by second ELISA technique were confirmed using Immunocomb (Orgenics, Isreal) or Western blot (Biotech, Ireland). The EDTA anti-coagulated blood (2 milliliters) was used for CD4positive lymphocyte evaluation using the flow cytometric technique. Here, 20 microliters of whole blood were added to 20 microliters of anti-CD4 monoclonal antibody. The mixtures were incubated in dark cupboard for about 10 minutes before adding 800 microlitre of buffer solution to the tube. Thereafter, the entire mixture was transferred to the flow cytometer for evaluation of the $\mathrm{CD} 4^{+}$lymphocyte count of the patient. The ESR was determined using the Westergren graduated tube method. There were two sedimentation rate methods that were most commonly used: the Westergren and Wintrobe methods. Careful comparisons of these two methods indicated a greater sensitivity for the Wintrobe method in lower sedimentation rate ranges, but a greater sensitivity of the Westergren method in higher ranges [46]. For the purpose of this study, a 200 millimeters open-ended plastic Westergren-type pipette with an internal diameter of 2.55 millimeters which is disposable was used. This selected Westergren method was used at 4:1 dilution of blood collected in the EDTA plastic bottle. This involved adding 1.6 milliliters of thoroughly mixed whole blood from EDTA anticoagulated bottle to 0.4 millilitres of sodium citrate anticoagulant in a small container (4:1 dilution).Thereafter, the diluted blood was placed in the ESR stand where a Westergren graduated pipette tube was inserted and positioned vertically. Using a safe suction method, the blood was drawn to the zero (0) mark of the graduated Westergren pipette tube while avoiding air bubbles. At one hour (60 minutes), the meniscus at the top of the sedimented red cells was noted and recorded as the ESR. After reading the ESR, the pipette was carefully removed soaked in sodium hypochlorite disinfectant while the container was decontaminated. The tube was placed vertically, not under direct sunlight and was within ambient temperature. The test must not be delayed beyond 4 hours if the sample is not refrigerated and must be read at exactly one hour $[47,48]$.

Other basic hematological tests include the evaluation of some parameters in complete blood count $(\mathrm{CBC})$ such as hematocrit, absolute white blood count (WBC), absolute lymphocyte count and platelet counts. The hematocrit was estimated using microhematocrit reader after centrifugation for 3-5 minutes at 12000-15000 XG to obtain constant packing of the red cells. The absolute WBC and platelet count were evaluated using the Improved Neubauer ruled counting chamber after mixing the blood (20 microliters) with the appropriate 
Citation: Nwabuko OC (2018) Relationship between some Hematologic Parameters (ESR, CBC) and CD4-Positive Lymphocyte Count in HIV SeroPositive Anti-Retroviral-Naïve Individuals with Tuberculosis Co-Infection. J Blood Lymph 8: 212. doi:10.4172/2165-7831.1000212

Page 6 of 10

diluting fluid (380 microliters each, i.e., $1 \%$ gentian violet mixed with the glacial acetic acid solution for WBC; filtered ammonium oxalate for platelet count).

The differential blood count was obtained using a mechanical differential white cell counter which was used to estimate different white cells present in Romanowsky-stained thin blood film of the patients.

\section{Statistical Analysis}

All data were entered and analyzed using EPI info statistical software version 6.02. Statistical analysis of mean and standard deviation was calculated. Student t-test was used to test the significance of differences between mean values. A probability (p) less than 0.05 were taken to indicate statistical significance.

\section{Result}

\section{Clinical characteristics of the patients}

A total of fifty patients (50) aged 20-55 years (mean age 34.1 \pm 8.1 years) were studied, out of which $35(70 \%)$ were females and $15(30 \%)$ males (M: F ratio was 1:2). Forty-eight (96\%) were symptomatic while $2(4 \%)$ were asymptomatic as at the time of investigations. Twenty-four (48\%) of the symptomatic patients had AIDS-defining illnesses, 3 (6\%) had Pulmonary Tuberculosis, $4(8 \%)$ had cutaneous manifestations (skin lesions such as fungal infections, seborrheic dermatitis, herpes simplex and herpes zoster) while 17(34\%) had other forms of nonspecific illnesses. There were 50 controls made up of healthy HIVnegative donors out of which 41 were male and 9 were female (Table 1).

\section{Laboratory parameters}

The mean $( \pm \mathrm{SD})$ CD4-positive lymphocyte count of the HIV infected patients was $217.7 \pm 144.8$ cells/ $\mu$ l while that of control was $896.2 \pm 198.0 \mathrm{cell} / \mathrm{s} / \mu \mathrm{l}$. The mean CD4-positive lymphocyte count of the HIV infected patients was significantly reduced compared to that of the healthy control population $(p<0.05)$. The mean $( \pm$ SD) ESR of the HIV infected patients was $97.4 \pm 39.9 \mathrm{~mm} / \mathrm{hr}$ and that of control was $10.1 \pm$ $5.7 \mathrm{~mm} / \mathrm{hr}$. The mean ESR of the HIV infected patients was significantly higher than that of the healthy control group $(p<0.05)$. There was no significant difference between the ESR of symptomatic patients (97.8 \pm $40.2 \mathrm{~mm} / \mathrm{hr})$ compared to that of asymptomatic patients $(86.0 \pm 36.8$ $\mathrm{mm} / \mathrm{hr})(\mathrm{p}>0.05)$. The mean ESR $(86.0 \pm 36.8 \mathrm{~mm} / \mathrm{hr})$ of asymptomatic patients was significantly higher than those of the control group (10.1 $\pm 5.7 \mathrm{~mm} / \mathrm{hr})(\mathrm{p}<0.05)$. Similarly, based on the classification of the HIV infected patients into groups I - III (according to their CD4-positive lymphocyte counts), the mean ESR of groups I (100.9 $\pm 42.2 \mathrm{~mm} /$ $\mathrm{hr})$ and II $(101.1 \pm 32.0 \mathrm{~mm} / \mathrm{hr})$ was statistically higher than those of group III $(70.1 \pm 52.7 \mathrm{~mm} / \mathrm{hr})$ respectively $(\mathrm{p}<0.001)$. The mean ESR of those in group I was not significantly higher than those in group II $(p=0.979)$. There was no significant sex variation of the ESR of both the HIV infected patients $(\mathrm{p}=0.079)$ and that of healthy control group (0.607) (Tables 1 and 3). The mean ( \pm SD) Total WBC of HIV infected patients was 5,268 $\pm \mathrm{I}, 601$ cells/ $\mu$ l while that of the controls was $5,454 \pm$ 2,283 cells/ $\mu$ l. There was no significant difference between Total WBC of the HIV infected patients and that of the healthy control population $(p=0.638)$ (Table 2). The mean $( \pm$ SD) Total Lymphocyte Count of HIV infected patient was 3,500 $\pm 1,131$ cells/ $\mu$ l while that of controls was $4,746 \pm 1,263$ cells/ul $(\mathrm{p}=0.000)$.There was a significant difference between Total Lymphocyte Count of HIV infected patients and that of the healthy control population $(p<0.001)$. The mean $( \pm S D)$ Packed cell volume $(\mathrm{PCV})$ of HIV infected patients was $0.33 \pm 0.061 \mathrm{~L} / \mathrm{L}$ $(10.9 \pm 2.0 \mathrm{~g} / \mathrm{dl})$ while that of the controls was $0.43 \pm 0.045 \mathrm{~L} / \mathrm{L}(14.3$ $\pm 1.5 \mathrm{~g} / \mathrm{dl})$. Similarly, the mean PCV/Hemoglobin concentration of HIV infected patients was significantly lower than that of the healthy control population $(\mathrm{p}<0.001)$. The mean $( \pm \mathrm{SD})$ platelet count of HIV infected patients was $157,000 \pm 81,979$ cells/ $\mu$ l while that of controls was $197,660 \pm 48,742 \mathrm{cells} / \mu \mathrm{l}(\mathrm{p}=0.003)$. The mean platelet count of HIV infected patients was significantly lower than that of the healthy control population $(\mathrm{p}=0.003)$. The mean $( \pm \mathrm{SD})$ Body Mass Index (BMI) of the HIV infected patients was $23.22 \pm 3.025 \mathrm{~kg} / \mathrm{m}^{2}$ while that of the controls was $24.52 \pm 2.68 \mathrm{~kg} / \mathrm{m}^{2}$. The mean BMI of HIV infected patients was significantly lower than that of the healthy control population $(\mathrm{p}=0.025)$. These participants were stratified under three CD4-positive lymphocyte count groups. Group I $(<200$ cells/ $\mu$ l) had 22 patients (44\%); II (200-499 cells/ $\mu \mathrm{l})$ had 22 patients $(44 \%)$ and III (> 500 cells/ $\mu \mathrm{l})$ had 6 patients $(12 \%)$.

The same findings as explained above was found in HIV infected patients in groups I and II. (Table 2).Group III had similar findings with groups I and II except that there was no statistically significant difference in the platelet count $\left(184,500 \pm 49,513\right.$ cells $\left./ \mathrm{mm}^{3} ; \mathrm{p}>0.05\right)$ of group III with that of control $\left(197,660 \pm 48,742 / \mathrm{mm}^{3}\right)$. The BMI $\left(23.60 \pm 2.33 \mathrm{~kg} / \mathrm{m}^{2} ; \mathrm{p}>0.05\right)$ of HIV infected patients in group III $(\geq$ $500 \mathrm{cells} / \mu \mathrm{l})$ is identical with that of the healthy control group $(24.52$ $\pm 2.68 \mathrm{~kg} / \mathrm{m}^{2}$ ). This was contrary to what was seen in groups I and II where platelet count and BMI were significantly reduced compared to the healthy control population (Table 3). Therefore, BMI is a function of a CD4 count.

\section{Comparison of CD4-positive lymphocyte count and ESR of HIV/TB Co-infected patients and that of HIV-infected pa- tients without $\mathrm{TB}$ co-infection}

The mean $( \pm$ SD) CD4-positive lymphocyte count of HIV/TB coinfected patients was $128.7 \pm 114.0$ cells/ $\mu$ l while that of HIV-infected

\begin{tabular}{|c|c|c|c|c|c|}
\hline & Group & $\underset{(n)}{\text { Number }}$ & 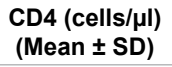 & $\begin{array}{l}\mathrm{ESR}(\mathrm{mm} / \mathrm{hr}) \\
(\mathrm{mean} \pm \mathrm{SD})\end{array}$ & p-value \\
\hline \multirow[t]{3}{*}{ Control } & & 50 & $896.2 \pm 198.0$ & $10.1 \pm 5.7$ & \\
\hline & Male & 41 & $903 \pm 210.4$ & $9.6 \pm 5.4$ & \multirow[t]{2}{*}{0.607} \\
\hline & Female & 9 & $865 \pm 132.7$ & $12.4 \pm 6.5$ & \\
\hline \multirow[t]{7}{*}{ Patient } & & 50 & $217.7 \pm 144.8$ & $97.36 \pm 39.8$ & \\
\hline & Female & 35 & $236.4 \pm 118.9$ & $95.2 \pm 40.7$ & \multirow[t]{2}{*}{0.079} \\
\hline & Male & 15 & $174.1 \pm 94.3$ & $102.5 \pm 38.7$ & \\
\hline & Asymptomatic & 2 & $330.0 \pm 169.7$ & $86.0 \pm 36.8$ & \multirow[t]{2}{*}{0.685} \\
\hline & Symptomatic & 48 & $213.1 \pm 112.1$ & $97.8 \pm 40.2$ & \\
\hline & With PTB & 3 & $128.7 \pm 114.0$ & $134.0 \pm 24.2$ & \multirow[t]{2}{*}{0.168} \\
\hline & $\begin{array}{l}\text { With pigment Others: Non- } \\
\text { specific symptoms }\end{array}$ & $\begin{array}{c}4 \\
17\end{array}$ & $\begin{array}{l}240.5 \pm 68.9 \\
267.2 \pm 53.4\end{array}$ & $\begin{array}{l}104.1 \pm 24.3 \\
82.7 \pm 28.5\end{array}$ & \\
\hline
\end{tabular}

Table 1: Distribution of ESR and CD4-positive lymphocyte count among study group 
Citation: Nwabuko OC (2018) Relationship between some Hematologic Parameters (ESR, CBC) and CD4-Positive Lymphocyte Count in HIV SeroPositive Anti-Retroviral-Naïve Individuals with Tuberculosis Co-Infection. J Blood Lymph 8: 212. doi:10.4172/2165-7831.1000212

Page 7 of 10

\begin{tabular}{|c|c|c|c|c|}
\hline Measured Parameters & $\begin{array}{c}\text { Control Subjects } \\
\text { Means } \pm S D \\
(N=50)\end{array}$ & $\begin{array}{c}\text { HIV-infected Patients } \\
\text { Means } \pm S D \\
(\mathrm{~N}=50)\end{array}$ & p-value & Statistical Inference \\
\hline $\mathrm{ESR}(\mathrm{mm} / \mathrm{hr})$ & $10.1 \pm 5.7$ & $97.4 \pm 39.9$ & $<0.05$ & Significant \\
\hline Total WBC(cellsmm³) & $5.454 \pm 2.283$ & $5.268 \pm 1.601$ & 0.63 & Not significant \\
\hline TLC (cells/mm³) & $4.746 \pm 1.263$ & $3.500 \pm 1.131$ & 0.000 & Significant \\
\hline PCV (L/L) & $0.43 \pm 0.045$ & $0.33 \pm 0.061$ & 0.000 & Significant \\
\hline Platelets (cells $/ \mathrm{mm}^{3}$ ) & $197.660 \pm 48.742$ & $157.000 \pm 81.979$ & 0.003 & Significant \\
\hline BMI $\left(\mathrm{kg} / \mathrm{m}^{2}\right)$ & $24.52 \pm 2.68$ & $23.22 \pm 3.03$ & 0.025 & Significant \\
\hline
\end{tabular}

NB: The above table is applicable to groups I and II.

Table 2: Hematological Parameters of HIV- infected patients compared with that of healthy control group.

\begin{tabular}{|c|c|c|c|c|}
\hline Measured Parameters & $\begin{array}{l}\text { Control subjects } \\
\text { Mean } \pm \text { SD } \\
(n=50)\end{array}$ & $\begin{array}{c}\text { HIV-infected patients. } \\
\text { Mean } \pm \text { SD } \\
(n=6)\end{array}$ & p-value & Statistical inference \\
\hline $\mathrm{ESR}(\mathrm{mm} / \mathrm{hr})$ & $10.1 \pm 5.7$ & $70.67 \pm 52.74$ & 0.0391 & Significant \\
\hline PCV(L/L) & $0.43 \pm 0.045$ & $0.33 \pm 0.08$ & 0.0223 & Significant \\
\hline WBC(cells/mm³) & $5,454 \pm 2,283$ & $5,050 \pm 804$ & 0.241 & Not Significant \\
\hline TLC(cells $/ \mathrm{mm}^{3}$ ) & $4,746 \pm 1,263$ & $3,283 \pm 691$ & 0.000 & Significant \\
\hline Platelet count $\left(/ \mathrm{mm}^{3}\right)$ & $197,660 \pm 48,742$ & $184,500 \pm 49,513$ & 0.062 & Not Significant \\
\hline $\operatorname{BMI}\left(\mathrm{kg} / \mathrm{m}^{2}\right)$ & $24.5 \pm 2.68$ & $23.60 \pm 2.33$ & 0.069 & Not Significant \\
\hline
\end{tabular}

ESR: Erythrocyte Sedimentation Rate; PCV: Packed Cell Volume; WBC: White Blood Count; TLC:Total Lymphocyte Count; BMI=Body Mass Index.

Table 3: Hematological parameters of HIV-infected patients in group III and that of controls.

\begin{tabular}{|c|c|c|c|c|c|}
\hline Group & $\begin{array}{l}\text { CD4-positive lymphocyte range } \\
\text { (cells } / \mu \mathrm{l})\end{array}$ & $\begin{array}{l}\text { Number } \\
\text { (n) }\end{array}$ & $\begin{array}{l}\text { Mean ESR }(\mathrm{mm} / \mathrm{hr}) \\
(\mathrm{X} \pm \mathrm{SD})\end{array}$ & p-value & $\begin{array}{l}\text { Statistical } \\
\text { inference }\end{array}$ \\
\hline 1 & $<200$ & 22 & $100.9 \pm 42.2$ & 0.979 & Not significant \\
\hline II & $200-499$ & 22 & $101.1 \pm 32.0$ & & \\
\hline III & $\geq 500$ & 6 & $70.7 \pm 52.7$ & 0.000 & Significant \\
\hline
\end{tabular}

$\mathrm{p}=0.979(\mathrm{I}$ and II)

$\mathrm{p}<0.0001$ (II and III)

Table 4: Group stratification of mean erythrocyte sedimentation rate (ESR) of HIV sero-positive subjects based on CD4-positive lymphocyte count distribution

patients without TB co-infection was $223.4 \pm 113.7$ cells $/ \mu$ l. There was no significant difference between the CD4-positive lymphocyte count of HIV/TB co-infected patients with that of HIV infected without TB coinfection ( $p>0.05)$ (Table 1). Similarly, the mean $( \pm$ SD) ESR of HIV/TB co-infected patients $(134.0 \pm 24.2 \mathrm{~mm} / \mathrm{hr})$ was not significantly higher than that of HIV infected patients without TB co-infection $(95.0 \pm$ $39.6 \mathrm{~mm} / \mathrm{hr})(\mathrm{p}=0.1005)$. The mean CD4-positive lymphocyte count of HIV infected patient with cutaneous manifestations ( $240.5 \pm 68.9$ cells/ $\mu \mathrm{l})$ was higher than that of patients with HIV/TB co-infected patients but the difference was not significant $(p>0.05)$ Similarly, the mean ( \pm SD) ESR of HIV infected patients with cutaneous manifestations $(104.1 \pm 24.3 \mathrm{~mm} / \mathrm{hr})$ when compared to that of HIV/TB co-infected patients there was no statistical significant difference $(\mathrm{p}>0.05)$ (Table 1). There was an inverse correlations between ESR of patients with their hematocrit $(\mathrm{PCV})(\mathrm{r}=-0.43 ; \mathrm{p}<0.001)$. A poor inverse relationship was also found between ESR of the healthy control group and their hematocrit $(\mathrm{r}=-0.15 ; \mathrm{p}<0.05)$ (Table 4$)$. There was a poor inverse correlations between the patients' CD4-positive lymphocyte count and their ESR $(r=-0.18 ; p<0.001)$. An inverse relationship was seen between healthy control CD4-positive lymphocyte count and their ESR ( $\mathrm{r}=-0.11$; $\mathrm{p}<0.001$ ) (Table 4). There was also a poor inverse correlation between both the patients' and control ESR with their respective total WBC and platelet counts $(\mathrm{r}=-0.23 ; \mathrm{p}<0.05 ; \mathrm{r}=-0.26 ; \mathrm{p}<0.05),(\mathrm{r}=-0.05 ; \mathrm{r}=-0.10$; $\mathrm{p}<0.05)$. There was a weak direct correlation between the patients and the control ESR with their Absolute Lymphocyte Count (ALC) ( $r=0.07$; $\mathrm{p}<0.05),(\mathrm{r}=0.25 ; \mathrm{p}<0.05)$ respectively. On the other hand, there was a poor inverse relationship between CD4-positive lymphocyte count and Absolute Lymphocyte Count (ALC) in the patients ( $r=-0.18$; $\mathrm{p}>0.0001)$. Similarly, there was a poor inverse correlation between
ESR of the patients and healthy control group with their BMI $(\mathrm{r}=-0.28$; $\mathrm{p}<0.05$; and $\mathrm{r}=-0.15 ; \mathrm{p}<0.05$ ) respectively (Table 5).

\section{Discussion}

From this study, the patients' absolute mean CD4-positive lymphocyte counts $(217.1 \pm 114.8$ cells/ $\mu$ l) appeared to be relatively higher than values obtained in previous studies by Ndakotsu and coworkers [49] among their cohort of $104 \mathrm{HIV}$-infected subjects in Ife where a mean value of $155.4 \pm 90.6$ cells/ $\mu \mathrm{l}$ was obtained from patients. This may be attributable to increased level of awareness of HIV infection in this region as the patients present early in our clinic. This study showed that about $88 \%$ and $12 \%$ of HIV sero-positive patients in the Niger Delta Nigeria have CD4-positive lymphocyte counts below 500 cells $/ \mu \mathrm{l}$ and above 500 cells $/ \mu \mathrm{l}$ respectively. We observed a control mean CD4-positive lymphocyte count of $896.2 \pm 198.0$ cells/ $\mu$ l among HIV-negative healthy blood donors residing in Port-Harcourt in the Niger Delta region of Nigeria. This was consistent with values reported in previous studies by Idoko and co-workers [50] $(821 \pm 12 \mathrm{cells} / \mu \mathrm{l})$ in Jos, North Central Nigeria, but relatively higher than values reported in previous studies by Ejele and co-workers [7] (685 $\pm 99 \mathrm{cells} / \mu \mathrm{l})$ in PortHarcourt, South-South Nigeria in 2005 and Ndakotsu and co-workers [49] (655.7 \pm 17.6 cells/ $\mu$ l) in Ife, South-West Nigeria in 2008. This may be due to improved nutritional status among the healthy HIV-negative controls coupled with increasing awareness of the populace. The mean CD4-positive lymphocyte count of HIV/TB co-infected patients (128.7 $\pm 114.8 \mathrm{cells} / \mu \mathrm{l}$ ) obtained from this study was not significantly lower than that of HIV sero-positive patients who were tuberculosisnegative $(223.4 \pm 113.7$ cells $/ \mu l)(p>0.05)$.This could be explained by the fact that tuberculosis affects person with HIV infection earlier than other 
Citation: Nwabuko OC (2018) Relationship between some Hematologic Parameters (ESR, CBC) and CD4-Positive Lymphocyte Count in HIV SeroPositive Anti-Retroviral-Naïve Individuals with Tuberculosis Co-Infection. J Blood Lymph 8: 212. doi:10.4172/2165-7831.1000212

\begin{tabular}{|c|c|c|c|}
\hline $\begin{array}{c}\text { Measured } \\
\text { parameters }\end{array}$ & $\begin{array}{c}\text { CD4+ counts } \\
(/ \boldsymbol{\mu l})\end{array}$ & $\begin{array}{c}\text { r-value } \\
\text { HIVsero-positive }\end{array}$ & $\begin{array}{c}\text { r-value } \\
\text { control }\end{array}$ \\
\hline ESR & CD4+ & -0.18 & -0.11 \\
& ESR & - & -- \\
\hline PCV & CD4+ & 0.07 & 0.31 \\
& ESR & -0.43 & -0.15 \\
\hline WBC & CD4+ & -0.04 & -0.08 \\
& ESR & -0.23 & -0.05 \\
\hline ALC & CD4+ & 0.18 & 0.24 \\
& ESR & -0.07 & -0.25 \\
\hline Platelet Count & CD 4+ & 0.05 & 0.08 \\
& ESR & -0.26 & -0.10 \\
\hline BMI & CD4+ & -0.18 & -0.22 \\
& ESR & -0.28 & -0.15 \\
\hline
\end{tabular}

Table 5: The Pattern of statistical correlations between CD4-positive count, ESR and Hematological parameters in HIV sero-positive and healthy control group.

opportunistic infections. A Recent study by Patel and co-workers [34] show that immune deficiency as traditionally defined by CD4 positive lymphocyte count does not account for the association of HIV and tuberculosis as it does for nearly all other opportunistic infections. Although the HIV/TB co-infected patients fall within the AIDSdefining CD4-positive lymphocyte count in this study, patients with CD4-positive lymphocyte count $>200$ cells/ $\mu$ l can be susceptible to tuberculosis. However, there is a need for an opportunistic infection alert in view of the low CD4 count in HIV infected patients. The data showed that the mean ESR of the symptomatic $(97.8 \pm 40.2 \mathrm{~mm} / \mathrm{hr})$ and asymptomatic $(86.0 \pm 36.8 \mathrm{~mm} / \mathrm{hr})$ patients were significantly higher than that of the control $(10.0 \pm 5.7 \mathrm{~mm} / \mathrm{hr})(\mathrm{p}<0.001)$. This was consistent with the previous studies by Ndakotsu et al. [49] where the mean ESR of the symptomatic and asymptomatic patients were higher than that of the controls. The increase in ESR is because infection by Human Immunodeficiency Virus elicits an increase in the whole body's protein (including acute phase reactant proteins and lipoproteins) turnover. This increase in body's proteins is applicable to both symptomatic and asymptomatic HIV infected person [39]. In contrast to Ndaktosu et al. [49], there was no statistical difference between the mean ESR of symptomatic $(97.8 \pm 5.7 \mathrm{~mm} / \mathrm{hr})$ and asymptomatic patients $(86.0 \pm 36.8 \mathrm{~mm} / \mathrm{h})(\mathrm{p}>0.05)$. This could be due to small sample size of asymptomatic HIV infected (4\%) compared to symptomatic (96\%) patients from this study.

The mean ESR of HIV/TB $(134.0 \pm 24.2 \mathrm{~mm} / \mathrm{hr})$ co-infected patients was relatively higher than the mean ESR of HIV infected patients without tuberculosis but the difference was not statistically significant. This is because infection caused by Mycobacterium tuberculosis elicit similar body's proteins and cytokines (such as TNF-alpha, IL-6, IFNalpha) production as HIV infection. This could be responsible for the raised ESR in both groups which were relatively synergized in HIV/TB co-infected patients. A $6 \%$ incidence of tuberculosis among the patients in this study is in keeping with the previous study of $2.2-70 \%$ risk of developing tuberculosis in HIV-infected individuals [23-28]. There was a weak inverse relationship between ESR and $\mathrm{CD} 4^{+}$lymphocyte count that was not statistically significant in both patients and controls $(\mathrm{r}=-0.18$ and $\mathrm{r}=-0.11$ respectively) $(\mathrm{p}>0.05)$ (Table 5). This finding was in accordance with those of some previous studies [8,14,16,49,51-54] where ESR was found to be a sensitive predictive marker of HIV disease progression. Similarly, in this study, a 95\% sensitivity and 70\% positive predictive value was recorded with the ESR. However, it was of 5\% specificity. In contrast to the above finding, Vasque et al. [55] found ESR as a poor marker for deterioration in the clinical and immune status of HIV patients.

There was a statistically significant difference between the mean hematocrit $(\mathrm{PCV})$ of HIV infected patients $(0.33 \pm 0.06 \mathrm{~L} / \mathrm{L}$ or $10.9 \pm 2.0$ $\mathrm{g} / \mathrm{dl})$ and that of controls $(0.43 \pm 0.045 \mathrm{~L} / \mathrm{L}$ or $14.3 \pm 1.5 \mathrm{~g} / \mathrm{dl})(\mathrm{p}<0.001)$. However, there was a significant inverse correlation between patients' ESR and their hematocrit $(\mathrm{r}=0.46 ; \mathrm{p}<0.05)$. The inverse correlation was weak in the control group $(\mathrm{r}=-0.15)$. This was in keeping with previous findings $[38,49]$ in which significant inverse correlation was found between ESR and hematocrit $(\mathrm{p}<0.001)$. Low hematocrit, a common finding in HIV disease progression has a negative influence on ESR and could have contributed to the elevated ESR level in our patients. In addition to this, hypergammaglobulinemia, malnutrition, tropical diseases, which are also common findings in HIV/AIDS patients may contribute to the elevated ESR levels [39,50]. Therefore, HIV related anemia increases the need for blood transfusion.

The data showed that there was no statistically significant difference between the total WBC of HIV infected patients $(5,268 \pm 1,601$ cells/ $\mu \mathrm{l})$ and the controls $(5,454 \pm 2,283$ cells/ $\mu \mathrm{l})(\mathrm{p}>0.05)$. There was a weak inverse correlation between CD4 positive lymphocyte count and total WBC in both the controls and the patients. Although leukocyte proliferation and the synthesis of cytokines, immunoglobulin and positive acute phase proteins contribute to protein turnover in HIV infection, this may not be the finding in all cases. HIV patients may also present with leucopenia which could be immune-mediated especially that resulting from antineutrophil antibodies in some HIV- antibody positive patients [40]. Hence total WBC may not give a good prediction of disease progression.

Though the mean ALC of HIV infected patients $(3,500 \pm 1,131$ cells/ $\mu \mathrm{l})$ was statistically lower than that of controls $(4,746 \pm 1,263$ cells $/ \mu \mathrm{l})$ there was a weak direct correlation between the ESR and ALC of the patients $(r=0.07 ; p<0.05)$. Conversely, there was a weak indirect correlation between $\mathrm{CD} 4^{+}$lymphocyte count and ALC of both HIV infected patients $(r=-0.18 ; \mathrm{p}<0.05)$ and the controls $(r=-0.24$; $\mathrm{p}<0.01$ ). Previous studies by Shapiro and Ejele and co-workers showed that ALC could have a minimal predictive value to $\mathrm{CD} 4$ positive lymphocyte count but this was not demonstrated from this study. It could be that hyperplasia of the B-lymphocytes in the lymphoid follicle and polyclonal hypergammaglobulinemia as reported among HIV/ AIDS patients in Nigeria by Mohammed and co-workers [41] may be contributory to the above finding.

It was found that the mean platelet count of HIV infected patients in group I and II $(157,000 \pm 81,979$ cells $/ \mu \mathrm{l})$ was statistically lower than that of the controls $(197,660 \pm 48,742$ cells/ $\mu \mathrm{l})(\mathrm{p}=0.003)$ while that of group III HIV infected patient $(184,500 \pm 49,513$ cells/ $\mu \mathrm{l})$ was not significantly higher than that of the controls $(\mathrm{p}=0.069)$. However, there was a weak direct correlation between $\mathrm{CD} 4^{+}$lymphocyte counts and platelet counts of the patients $(\mathrm{r}=0.05 ; \mathrm{p}<0.05)$ and their controls $(\mathrm{r}=0.08 ; \mathrm{p}<0.05)$, while a weak inverse correlation between the ESR value and the platelet count of the patients was found from this study. This decrease in platelet count with disease progression may be immune-mediated as immune thrombocytopenia is a common finding in AIDS [40,43].

The mean BMI of group I and II HIV infected patients $(23.22 \pm$ $\left.3.025 \mathrm{~kg} / \mathrm{m}^{2}\right)$ were significantly lower than that of the controls $(24.52$ $\left.\pm 2.68 \mathrm{~kg} / \mathrm{m}^{2}\right)$. The BMI of group III patients $\left(23.60 \pm 2.23 \mathrm{~kg} / \mathrm{m}^{2}\right)$ was nearly identical with that of the control $(p>0.05)$. Hence, this implies that there is a progressive decrease in weight as HIV disease progresses to the advanced stage. However, the BMI of the patients in this study fell within a normal range of 18.5-24. 9 stipulated by World Health Organization (WHO). There was a weak inverse relationship between ESR and BMI in this $\operatorname{study}(\mathrm{r}=-0.28 ; \mathrm{p}<0.05)$. The 
Citation: Nwabuko OC (2018) Relationship between some Hematologic Parameters (ESR, CBC) and CD4-Positive Lymphocyte Count in HIV SeroPositive Anti-Retroviral-Naïve Individuals with Tuberculosis Co-Infection. J Blood Lymph 8: 212. doi:10.4172/2165-7831.1000212

Page 9 of 10

weak inverse relationship between ESR and BMI could be explained by the increase catabolic rates, hypoalbuminemia, dyslipidemia (i.e., hypertriglyceridemia, lipodystrophy), malnutrition, in addition, to increase protein turnover in HIV infection and this may be linked to the wasting syndrome seen in an advanced stage of the disease [56]. This implies that nutritional therapy should be part of HIV standard care.

ESR was relatively higher in female $(12.4 \pm 6.5 \mathrm{~mm} / \mathrm{hr})$ than male $(9.6 \pm 5.4 \mathrm{~mm} / \mathrm{hr})$ in the controls but the difference was not statistically significant $(\mathrm{p}=0.607)$ (Table 1$)$. This was similar to the previous study where ESR was shown to be higher in female irrespective of infection or immune status [49].

There was a weak direct correlation between ESR and age in both the controls $(\mathrm{r}=0.26 ; \mathrm{p}<0.05)$ and HIV infected patient $(\mathrm{r}=0.04 ; \mathrm{p}<$ $0.05)$. This direct correlation was similar to the findings by the previous study by Ndaktosu and co-workers [49] where a significant correlation was reported in the controls but not in the patients. These may be due to increasing ESR as one age just as the hematocrit decreases with age $[38,49]$. Similarly, changes in the body's metabolic rates with the release of chemical mediators some of which may be acute phase proteins in the healthy and unhealthy individuals may have contributed to the above findings.

\section{Conclusion}

The conclusion made in the study of the relationship between some hematological parameters (ESR, CBC) and CD4-positive lymphocyte count in HIV infected antiretroviral-naïve individuals with tuberculosis co-infection in the Niger Delta region of Nigeria are:

- ESR of HIV sero-positive individuals irrespective of their clinical status (symptomatic or asymptomatic) is significantly higher than that of healthy HIV-sero-negative individuals.

- HIV/AIDS alters the immunological status of an individual, leading to deterioration of the clinical status.

- Though ESR may not be a useful surrogate for CD4-positive lymphocyte count because of the poor inverse correlation, it is a useful predictive marker of morbidity and mortality. Hence, there is a place for this cheap laboratory test in the diagnosis and monitoring of HIV/AIDS disease progression in resourcelimited centers like those in the Niger Delta region of Nigeria.

- ESR is one of the earliest predictive markers of disease progression long before CD4+ lymphocyte count falls.

- At high CD4-positive lymphocyte counts (>500 cells/ $\mu$ l) the platelet counts and BMI tend to that of healthy HIV seronegative individuals while the reverse is the case when the CD4-positive lymphocyte counts decrease $(<500$ cells $/ \mu \mathrm{l})$

- Anaemia and weight loss are indicators of poor nutritional status resulting from HIV infection.

\section{Acknowledgements}

The author wishes to thank the management and the department of Hematology, University of Port Harcourt Teaching Hospital, Rivers State, Nigeria for creating enabling environment for this research work.

\section{Disclosure}

The author reports no conflicts of interest in this work.

\section{References}

1. UNAIDS (2007) Joint United Nations Program on HIVIAIDS. AIDS epidemic update. UNAIDS information center and World Health Organization (WHO) UNAIDS/O7.27E/JC1322E

2. UNAIDS (2006) Joint United Nations Program on HIVIAIDS. AIDS epidemic update. UNAIDS information center in collaboration with World Health Organization (WHO). UNAIDS/06.29E.

3. National HIV/Syphilis Sentinel Survey Reports (2006) Nigerian Federal Ministry of Health.

4. Modified National Policy on HIVIAIDS (2004) Federal Ministry of Health in collaboration with Federal Government of Nigeria.

5. Erhabor O, Uko EK, Adias T (2006) Correlation between absolute and CD4 Lymphocyte counts in HIV-infected Nigerians. Can absolute lymphocyte count serve as surrogate for CD4 cell count in resource-limited setting? Niger J Med 15: 56-59.

6. Castro B, Cheng-Meyer C, Evans LA, Levy JA (1988) HIV heterogeneity and viral pathogenesis. AIDS 2: 17-27.

7. Erhabor O, Nwauche CA, Ejele OA, Babatunde S (2005) CD4+ lymphocyte reference ranges in healthy adults in Port-Harcourt, Nigeria. Sahel Med J 8 : $71-75$

8. Lefrere JJ, Salmon D, Doinel C, Rouger P, Courouce AM, et al. (1988) Sedimentation rate as a Predictive marker in HIV infection. AIDS: 2: 63-64.

9. Ejele OA, Ojule AC (2001) Human Immunodeficiency Virus (HIV) 1 and 2 Screening in University of Port Harcourt Teaching Hospital: A Ten-year review (1989-1998). Niger J Clin Pract 4: 64-68.

10. Erhabor O, Nwauche CA, Ejele OA (2006) The Effects of Highly Active Antiretroviral Therapy (HAART) of Stavudine, Lamivudine and Nevirapine on the CD4-positive lymphocyte count of HIV-infected Africans: The Nigerian Experience. Niger J Clin Pract 9: 128-133.

11. Ejele OA, Erhabor O, Uko EK (2006) HAART-dependent CD4-positive lymphocyte Response based on Pre-therapeutic CD4 lymphocyte count in HIVinfected Nigerians. Ann Afr Med 5: 153-157.

12. Morley JJ, Kushner IC (1982) Reactive protein levels in disease. Ann NY Acad Science 389: 406-416.

13. Adewuyi JO (2007) Companion to Practical Haematology, Illorin: Klobex Academic Publishers: 24-26.

14. Swartlander B, Bek B (1993) Improvement of Predictive value of CD4 count by beta 2-microglobulin, IgA and ESR. A multicentre cohort study group. Federal Health Office Berlin Germany. AIDS 7.

15. Katz MH (1991) Risk stratification of ambulatory patients suspected of Pneumocystis Carinii Pneumonia. Arch Gen Intern Med 151: 105-110.

16. Papadopoulos EE, Turner VF, Papadimitriou JM (2003) High rates of HIV seropositivity in Africa-alternative explanation. International Journal of STD and AIDS

17. Des Jarlais DC, Friedman SR, Marmor M, Mildvan D, Yancovitz S, et al. (1996) CD4 lymphocytopenia among injecting drug users in New York City. J Acquir Immune Defic Syndr 6: 820-822.

18. Pitchenik AE (1987) HTLV-III Seropositivity and related diseases among 71 consecutive patients in whom tuberculosis was diagnosed. A prospective study. Am Rev Respir Dis 135: 875-9.

19. Sunderham G, McDonald RJ, Maniatis T, Oleske J, Kapila R, et al. (1986) Tuberculosis as a manifestation of the Acquired Immunodeficiency Syndrome (AIDS). JAMA 256: 362-366.

20. Van de Perre P, Rouvroy D, Lepage P, Bogaerts J, Kestelyn P, et al. (1984) Acquired immunodeficiency syndrome in Rwanda, Africa. Lancet 2: 62-65.

21. Selik RM, Starcher ET, Curran JW (1987) Opportunistic disease reported in AIDS patients: frequencies, associations and trends. AIDS 1: 175-182.

22. Pitchenik AE, Cole C, Russell BW, Fischl MA, Spira TJ, et al. (1984) Mycobacteriosis and the acquired immunodeficiency syndrome among Haitian and Non-Haitian patients in South Florida. Ann Intern Med 101: 641-645.

23. Akanmu AS, Akinsete I (1998) Epidemiology of HIVIAIDS in Nigeria. Nig Med Journal 34: 21-23.

24. Habib AG (1995) HIV and Tuberculosis in Zaria, Nigeria. Nigerian Medica Pract: $30-31$. 
Citation: Nwabuko OC (2018) Relationship between some Hematologic Parameters (ESR, CBC) and CD4-Positive Lymphocyte Count in HIV SeroPositive Anti-Retroviral-Naïve Individuals with Tuberculosis Co-Infection. J Blood Lymph 8: 212. doi:10.4172/2165-7831.1000212

Page 10 of 10

25. Anteyi EA, Idoko JA, Ukoli CO, Bello CSS (1996) Clinical Pattern of Human Immunodeficiency Virus Infection (HIV) in Pulmonary Tuberculosis patients in Jos, Nigeria. African J Med Sci 25: 317-321.

26. Dosummu EA (2000) Prevalence of HIV among Newly diagnosed Pulmonary Tuberculosis in a semi urban settlement of Osun state, Nigeria. The Nig J Gen Pract 4: 1.

27. Ogun SA, Adelowo OO. (1999) Frequency and outcome in AIDS patients in a university teaching hospital: A five year review. Nig Qt J Hosp Med 9: 177-179.

28. Wokoma FS (1997) Human Immunodeficiency Virus (HIV) Status of adult Nigerian patients suffering from pulmonary tuberculosis. Nig Med Pract, pp: $31-33$

29. Davies GR, Onnolly C, Sturm AW, McAdam KP, Wilkinson D (1999) Twice weekly directly observed treatment for HIV-infected and uninfected tuberculosis patients: Cohort study in rural South Africa. AIDS 13: 811-817.

30. Van Cleeff MR, Chum HJ (1995) The proportion of tuberculosis cases in Tanzania attributable to human immunodeficiency virus. Intl J Epidermiol 24: $635-642$

31. Festenstein F, Grange JM (1991) Tuberculosis and the Acquired Immunodeficiency Syndrome. J Appl Bacteriol 71: 19-30.

32. Wallis RS, Vjecha M, Amir-Tahmasseb M, Okwera A, Byekwaso F, et al. (1993 Influence of tuberculosis on Human Immunodeficiency Virus (HIV): Enhanced cytokine expression and elevated B2 microglobulins in HIV- associated tuberculosis. J Infect Dis 167: 43-48.

33. Daley CL, Small PM, Schecter GF, Schoolnik GK, McAdam RA, et al. (1992) An outbreak of tuberculosis with accelerated progression among person infected with the Human Immunodeficiency Virus. An analysis using restrictionfragment-length polymorphism. New Engl J Med 326: 231-235.

34. Patel NK, Swan K, Xin L, Tachado SD, Koziel H (2009) Impaired M. tuberculosismediated apoptosis in alveolar macrophages from HIV+ persons: potential role of IL-10 and BCL-3. J Leukoc Bio 86: 53-60.

35. Seligman M (1984) AIDS-an immunologic re-evaluation. N Engl J Med 311: 1286-92.

36. Seriano V (1992) Idiopathic CD4 positive Iymphocytopenia. Lancet 340: 607608.

37. Shapiro NL (1998) Absolute Lymphocyte Count as a predictor of CD4 count. Ann Emerg Med 32: 323-8.

38. Hung WT, Collings AF, Low J (1994) Erythrocyte sedimentation rate studies in whole human blood. Physics in Medicine and Biology 39: 1855-1873.

39. Ogunro PS, Idogun ES, Ogungbamigbe TO, Ajala MO, Olowu OA (2008) Serum concentration of Acute phase proteins and lipid profile in HIV-1 seropositive patients and its relationship to the progression of disease. Niger Postgrad Med J 5: 219-224.

40. Costello C, Hoffbrand AV, Louis MS, Tuddenham EG (eds) (2001) The Hematological manifestations of HIV disease in Postgraduate Haematology, London. Arnold 4: 310-313.
41. Mohammed I (1990) AIDS in Nigeria. An immunological perspective. Nig J Immunol 2: 1-3.

42. Uko GP, Griffiths M, Dawkins RL (1994) IgG2 associated hypergammaglobulinemia in some Nigerians with HIV infections. Afri J Med Sci 23: 385-389.

43. Costello C, Hoffbrand AV, Catovsky D, Tuddenham EG (2005) Postgraduate Hematology in HIV diseases, Oxford. Blackwell 5: 383-385

44. National Bureau Statist.

45. WHO/UNAIDS (1998) Importance of simple/rapid assays of HIV testing. Wkly Epidemiol Rec 72: 321-328.

46. Bull BS (1981) Clinical and laboratory implications of present ESR methodology Clin Lab Hematol 3: 283-298.

47. ICSH (1993) Recommendations for measurement of erythrocyte sedimentation rate. J Clin Pathol 46: 198-203.

48. Koepke JA, Preston FE, Martin RM, Assendelft OW. Measuring the erythrocyte sedimentation rate. Advanced Laboratory Methods in Haematology. London, England. Arnold 2002: 10.

49. Ndakotsu MA, Salawu L, Durosinmi MA (2009) Relation between Erythrocyte Sedimentation Rate, Clinical and Immune status in HIV-infected patients: Niger Med J 17: 420-422.

50. Idoko JA, Idigbe JA, Njoku MO, Sirisena ND, Isamade ET et al. (2001) CD4 T-lymphocyte counts in Human Immunodeficiency Virus (HIV)-infected and Healthy Nigerian population. Niger Med Pract 39: 53-55.

51. Kayvan M, Isaac Z, Etienne K, Kancheya N, Funkhouser E, et al. (2005) Predictors of HIV serostatus among HIV discordant couples in Lusaka Zambia and female Antenatal Clinic Attendants in Kigali, Rwanda. AIDS Res Hum Retroviruses 21: 5-12.

52. Lindan CP, Allen S, Sanifilira A, Lifson AR, Van de Perre P, et al. (1992) Predictors of mortality among HIV-infected women in Kigali, Rwanda. Ann Intern Med 116: 320-328.

53. Lifson AR, Allen S, Wolf W, Serufilira A, Kantarama G, et al. (1995) Classification of HIV infection and disease in women from Rwanda. Evaluation of the World Health Organization HIV staging system and recommended modifications. Ann Intern Med 122: 262-270.

54. de Oteyza CP, Martinez MAM, Garcia RM, Aznar CP, Lopez JB (1998) Discriminative value for AIDS case of erythrocyte sedimentation rate immunoglobulins IgA and IgM, and beta 2-microglobulin in combination with the CD4 + lymphocyte count. An Med Intern 15: 411-414.

55. Vazque EG, de Gorgolas M, Guerrero ML (2001) Relation between ESR Clinical and Immune status, and viral load in non-hospitalized HIV-infected patients. Res Esp Ouimoiter 14: 264-268.

56. Contans J, Pellegrin JL, Peuchant E, Dumon MF, Pellegrin I, et al. (1994) Plasma Lipids in HIV-infected patients: a prospective study in 95 patients. Eur. $\mathrm{J}$ Clin Invest 24: 416-420. 